\title{
Pentynyl Ether of $\beta$-Cyclodextrin Polymer and Silica Micro-Particles: A New Hybrid Material for Adsorption of Phenanthrene from Water
}

\author{
Jae Min Choi ${ }^{1}$, Daham Jeong ${ }^{2}$, Eunae Cho ${ }^{1}$, Jae-Hyuk Yu ${ }^{3}$, Muhammad Nazir Tahir ${ }^{4, *}$ \\ and Seunho Jung ${ }^{1,2, *}$ \\ 1 Center for Biotechnology Research in UBITA (CBRU), Institute for Ubiquitous Information Technology and \\ Applications (UBITA), Konkuk University, 120 Neungdong-ro, Gwangjin-gu, Seoul 05029, Korea; \\ jm.choi.25@gmail.com (J.M.C.); 82goodgirl@hanmail.net (E.C.) \\ 2 Department of Systems Biotechnology, Microbial Carbohydrate Resource Bank (MCRB) \& Center for \\ Biotechnology Research in UBITA (CBRU), Konkuk University, 120 Neungdong-ro, Gwangjin-gu, \\ Seoul 05029, Korea; amir@konkuk.ac.kr \\ 3 Department of Bacteriology, The University of Wisconsin-Madison, Madison, WI 53706, USA; jyu1@wisc.edu \\ 4 Nanoqam, Department of Chemistry, University of Quebec at Montreal, P.O. Box 8888, Succ. Centre-ville, \\ Montreal, QC H3C 3P8, Canada \\ * Correspondence: mnazirtahir@gmail.com (M.N.T.); shjung@konkuk.ac.kr (S.J.); Tel.: +82-2-450-3520 (S.J.)
}

Academic Editors: Joannis K. Kallitsis, Georgios Bokias and Valadoula Deimede Received: 21 November 2016; Accepted: 29 December 2016; Published: 4 January 2017

\begin{abstract}
A new hybrid material for the removal of polycyclic aromatic hydrocarbons (PAH) from water was prepared by the polymerization of pentynyl beta-cyclodextrin $(\mathrm{Py} \beta C D)$ and silica micro-particles (SMP). Phenanthrene, being one of the important members of the PAH family and a potential risk for environmental pollution, was selected for this study. Results show that phenanthrene removal efficiency of the SMP was improved significantly after hybridization with Py $\beta C D$-polymer. Approximately $50 \%$ of the phenanthrene was removed in the first $60 \mathrm{~min}$ and more than $95 \%$ was removed in less than $7 \mathrm{~h}$ when $25 \mathrm{~mL}$ of the $2 \mathrm{ppm}$ aqueous phenanthrene solution was incubated with the $100 \mathrm{mg}$ of SMP-Py $\beta C D$-polymer material. Infrared spectroscopy and thermal gravimetric analysis show that the enhanced efficiency of the SMP-Py $\beta C D$-polymer compared to the unmodified SMP was due to the formation of the inclusion complexation of phenanthrene with the Py $\beta C D$. These results indicate that SMP-Py $\beta C D$ polymers have a potential to be applied as molecular filters in water purification systems and also for waste water treatment.
\end{abstract}

Keywords: pentynyl ethers of beta-cyclodextrin; silica micro-particles; hybridization; polycyclic aromatic hydrocarbons; inclusion complex

\section{Introduction}

Polycyclic aromatic hydrocarbons (PAH) are considered one of the most toxic and widespread pollutants which cause severe health problems not only for human beings, but also for other living organisms [1,2]. Coke-oven gas plants, refineries, and related chemical industries are the main sources of PAH emission into the environment [3]. Most of the PAH-producing industries are located near urban areas and, thus, represent a considerable public health threat [3]. Due to their persistent nature and toxic, mutagenic, and carcinogenic effects, the remediation of PAH-contaminated water is an important environmental issue. However, the low-water solubility of these components makes their removal from the contaminated water very difficult [1,2]. Phenanthrene, being one of the most important PAHs, composed of three fused benzene rings, was selected for investigation in this study. 
In previous years, a number of different adsorbents, like nanofibers, silica gel, porous nanoparticles, and other similar materials have been developed for the removal of PAHs [4-6] but most of such materials could not be applied at large scale for water purification due to their limited efficiency, high production cost or due to the involvement of complex synthetic procedures. Very low solubility of the PAH in water is another reason for the limited use of these kind of materials. However, there are a number of reports indicating that beta-cyclodextrin $(\beta C D)$ could increase the solubility of aromatic compounds $[7,8]$ and removal efficiency enhanced several times [3].

$\beta C D$ is a cyclic heptasaccharide composed of seven glucose units joined "head to tail" by an $\alpha-(1-4)$ glucopyranose unit link. $\beta C D$ has a toroid-shaped molecular structure with a relatively hydrophobic interior cavity at the center of its molecular arrangement, which can make a non-covalent reversible host-guest complexation with many molecules having a phenyl ring [9-12]. Due to host-guest inclusion complexation, $\beta C D$ is applied in pharmaceuticals, foods, cosmetics, textile, wound odor absorbants, composites, gene delivery, and in the other related industries [10,12-22]. Additionally, water filtration and purification systems are another field of application for $\beta C D$ molecules owing to their potential of encapsulating hazardous organic molecules [23-26]. Moreover, $\beta C D$ is preferred over the other adsorbents because it is biocompatible, environmentally friendly, non-toxic, non-hygroscopic, and chemically stable [27].

Depending upon the target applications, $\beta C D$ could be used in various forms, like chemical derivatives and polymers $[10,12,25]$. Polymerization of $\beta C D$ leads to the formation of a 3D network containing both hydrophobic and hydrophilic cavities [28]. Soluble hyper-cross-linked $\beta C D$ polymers are of great interest, e.g., in the encapsulation of organic molecules and inorganic ions [29], but could not be applied in removing pollutants from water. Water solubility of $\beta C D$ or its derivatives would restrict its applications for water purification systems due to the possibility of leaching from the surface during the filtration process [30]. Water insoluble $\beta C D$ polymers have their own advantages in specific applications e.g., nanosponges and hydrogels, for controlled drug delivery systems [15], encapsulation, and controlled release of agricultural chemicals [31], and for environmental applications [25]. Thus, natural CDs are often chemically modified to synthesize novel insoluble CD-derivatives. The patents published by Martel et al. [32] and Trotta et al. [33] can be consulted for the use of carboxylic acids and pyromellitic dianhydride, respectively, as agents to cross-linking CDs. Other cross-linking agents like epichlorohydrin $(\mathrm{ECH})$, ethylene glycol diglycidyl ether, glutaraldehyde, benzoquinone, isocyanates, and carbodiimidazole, etc., have also been reported [25,28,34]. In this list, ECH, due to its low cost, high reactivity and long bridges by self-polymerization, is the most commonly used cross-linking agent to prepare CD polymers [35,36]. However, low cross-linking density of ECH-based $\beta C D$-polymers tends to increase their water-solubility due to the long bridged chains of $\mathrm{ECH}$ that leads to disruptions in the intermolecular hydrogen bonding between $\beta C D$ and water molecules [37]. Therefore, we suggest applying a hybrid material prepared by the high-density polymerization of $\beta C D$ in the presence of silica micro-particles (SMP). SMP could, itself, be used for the adsorption of PAHs [38] but its efficiency could be enhanced significantly by its hybridization with $\beta C D$. Instead of using a simple $\beta C D$ polymer, we introduced pentynyl groups onto the $\beta C D$ surface $(\rightarrow \operatorname{Py} \beta C D, 2)$ by its etherification with pentynyl chloride followed by the polymerization and hybridization with SMP. Native $\beta C D$ is hydrophilic in nature due to the presence of a large number of $-\mathrm{OH}$ groups while its pentynylation $(\mathrm{Py} \beta C D, 2)$ leads to the introduction of carbon rich $-\mathrm{CH} 2-\mathrm{CH} 2-\mathrm{CH} 2-\mathrm{C} \equiv \mathrm{CH}$ residues, which introduce hydrophobic properties. The hydrophobic character of the PyßCD (2) could be varied by varying the degree of substitution (DS = average number of pentynyl groups introduced per glucosyl unit, $\max =3$ ). In addition, terminal acetylenic groups act as hydrogen bonding donors and acceptor, as well [39]. Thus, Py $\beta C D$ (2) enables several types of weak cooperative interactions [39] that could possibly support efficient PAH adsorption. Moreover, $\beta C D$ polymer is normally soluble in water and, thus, not suitable for water purification systems to remove PAHs, while Py $\beta C D$-polymer is insoluble due to the hydrophobic character introduced by the pentynyl groups. Herein, we report a simple process for the preparation of pentynyl $\beta C D(\operatorname{Py} \beta C D, 2)$ and its polymerization (Poly-Py $\beta C D, 3)$ 
using epichlorohydrin in the presence of SMP to prepare a hybrid material (Poly-SMP-Py $\beta C D, 4$ ) as a potential candidate to adsorb phenanthrene from the water.

\section{Experimental}

\subsection{Materials}

Silica micro-particles (av. $4 \mu \mathrm{m}$ in diameter) were purchased from Polyscience Inc., Warminster, PA, USA. $\beta C D(\geq 97 \%)$, acetone (99.9\%), dimethyl sulfoxide (DMSO, 99.9\%), $N, N$-dimethyl formamide (99.8\%), pentynyl chloride (PyCl, 98\%), epichlorohydrin ( $\geq 99 \%$ ), acetonitrile (High Perfomance Liquid Chromatography (HPLC) plus, $\geq 99.9 \%$ ), methanol ( $\geq 99.9 \%)$, hexane $(\geq 95 \%)$, and methyl lithium (1.6 M in diethyl ether) were purchased from Sigma-Aldrich, St. Louis, MO, USA. Py $\beta C D$ was obtained from Microbial Carbohydrate Resource Bank at Konkuk University, Seoul, Korea. Water used in all the experiments was purified using Direct-Q Millipore water purification system from Sam Woo Co., Ltd., Gyeonggi, Korea.

\subsection{Pentynylation of $\beta C D(P y \beta C D, 2)$}

$\beta C D$ (5 g, $4.40 \mathrm{mmol})$ was dissolved in $N, N$-Dimethylformamide $(100 \mathrm{~mL})$ followed by the addition of Li-dimsyl ( $3.88 \mathrm{~g}, 46.25 \mathrm{mmol}, 0.5 \mathrm{eq} . / \mathrm{OH})$ prepared according to the procedure as described earlier [27] and stirred for $1 \mathrm{~h}$. $\mathrm{PyCl}(4.74 \mathrm{~g}, 46.25 \mathrm{mmol}, 0.5 \mathrm{eq} . / \mathrm{OH})$ was also added and the mixture was stirred at room temperature for $24 \mathrm{~h}$ (Scheme 1). Solvent was evaporated under reduced pressure and residue was suspended in water and precipitated in acetone. The product was recrystallized from cold water and dried under vacuum as a white powder $(7.12 \mathrm{~g}) .{ }^{1} \mathrm{H}-\mathrm{NMR}(500 \mathrm{MHz}$, DMSO- $\left.d_{6}\right) \delta=1.68(\mathrm{~m}, 2 \mathrm{H}), 2.24(\mathrm{~m}, 2 \mathrm{H}), 2.71(\mathrm{~s}, 1 \mathrm{H}), 3.31-3.61(\mathrm{~m}, 40 \mathrm{H}), 4.13(\mathrm{~m}, 1 \mathrm{H}), 4.27-4.29(\mathrm{~m}, 1 \mathrm{H})$, $4.33(\mathrm{t}, 1 \mathrm{H}), 4.41(\mathrm{~m}, 2 \mathrm{H}), 4.48(\mathrm{t}, 3 \mathrm{H}), 4.72(\mathrm{~d}, 2 \mathrm{H}), 4.80(\mathrm{~m}, 5 \mathrm{H}), 5.02(\mathrm{~m}, 2 \mathrm{H}), 5.64-5.73(\mathrm{~m}, 14 \mathrm{H})$.

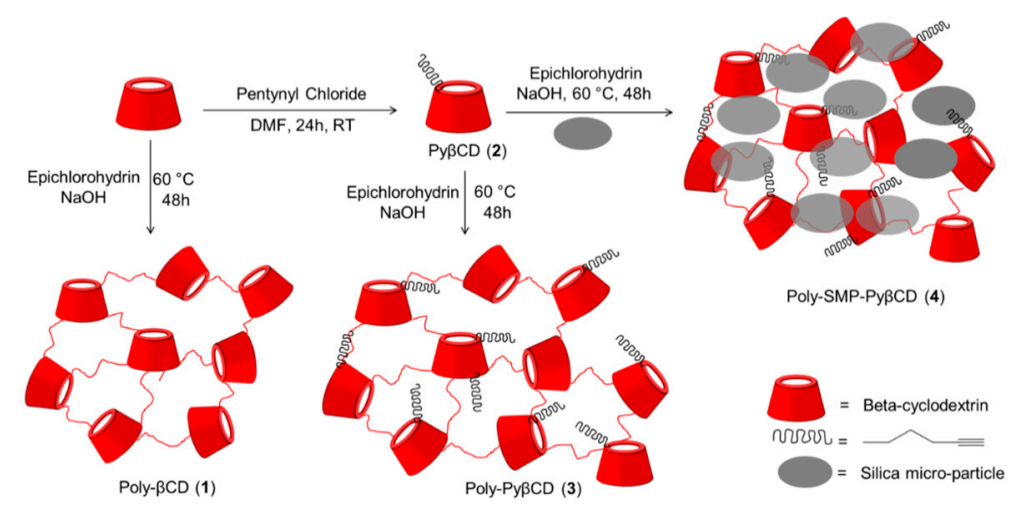

Scheme 1. Schematic representation for the synthesis of $\beta C D$ polymer (Poly- $\beta C D, 1)$, pentynyl ether of $\beta C D(\operatorname{Py} \beta C D, 2)$, polymer of Py $\beta C D$ (Poly-Py $\beta C D, 3$ ), and hybridization with SMP (Poly-SMP-Py $\beta C D, 4)$.

\subsection{Polymerization of Py $\beta C D(2 \rightarrow$ Poly-Py $\beta C D, 3)$ in the Presence of Silica Micro-Particles}

In a typical procedure, $2 \mathrm{~g}$ of $\mathrm{Py} \beta \mathrm{CD}(2)$ was added into $40 \mathrm{~mL}$ of water followed by the addition of $6.8 \mathrm{~mL}$ of the $20 \% \mathrm{NaOH}$. The mixture was stirred at $60{ }^{\circ} \mathrm{C}$ until a clear solution was obtained. Two grams of SMP was added and stirring of the mixture continued for $1 \mathrm{~h}$. After that, $162.84 \mathrm{mg}$ $(1.76 \mathrm{mmol})$ of epichlorohydrin $(\mathrm{ECH})$ was also added into the reaction mixture and continued stirring at $60{ }^{\circ} \mathrm{C}$. After $48 \mathrm{~h}$, reaction was stopped and product was purified by centrifugation (4000 $\mathrm{rpm} \times 20 \mathrm{~min} \times 4$ times), washed with methanol, hexane, and acetone (three times with each solvent) and dried in open air to obtain the hybrid composite material (Poly-SMP-Py $\beta C D, 4,3.94 \mathrm{~g}$ ). For comparison, $\beta C D$ and $\operatorname{Py} \beta C D(2)$ was also polymerized without SMP following the same procedure as described above and precipitated in acetone (Scheme 1). 


\subsection{Phenanthrene Removing Studies}

Phenanthrene was dissolved in minimum amount of the acetonitrile and diluted in water and analyzed by HPLC. The calibration curve of phenanthrene was prepared in preliminary studies by analyzing phenanthrene solutions from 1-6 ppm prepared by the serial dilution of the same stock solution. The curve showed linearity with $R^{2} \geq 0.99$. In the general procedure of phenanthrene removal from the aqueous solution, $100 \mathrm{mg}$ of the Poly-SMP-PyßCD (4) was incubated with the $25 \mathrm{~mL}$ of the $2 \mathrm{ppm}$ phenanthrene solution and samples ( $250 \mu \mathrm{L}$ each time) were drawn after every $20 \mathrm{~min}$ and analyzed by HPLC. The results (in terms of peak areas) were adapted to the calibration curve prepared in the preliminary studies.

\subsection{Characterization of the Materials}

Scanning electron microscopy (SEM) images were recorded with a JEOL JSM-6380 scanning electron microscope (JEOL Ltd., Tokyo, Japan). NMR spectra were recorded with a Bruker Avance III HD $300 \mathrm{MHz}$ spectrometer (Bruker, Billerica, MA, USA). Proton chemicals shifts are reported in ppm relative to the solvent signals. Thermal gravimetric analysis (TGA) was performed by means of a TG \TDA6200 thermal analyzer (Seiko instrument Inc., Chiba-shi, Japan), under a $100 \mathrm{~mL} \cdot \mathrm{min}^{-1}$ nitrogen stream and $5{ }^{\circ} \mathrm{C} / \mathrm{min}$ heating rate. X-ray photoelectron spectra (XPS) were recorded using a XPS PHI 5600-ci (Physical Electronics, Eden Prairie, MN, USA). Al-standard (1486.6 eV) was employed as the anode for a wide-scan spectra at $300 \mathrm{~W}$ ). High-resolution spectra were obtained with an $\mathrm{Mg}$ anode $(1253.6 \mathrm{eV})$ at $150 \mathrm{~W}$. The analyses were performed without charge compensation (neutralizer) at an angle of $45^{\circ}$ with respect to the surface. Infrared (IR) spectra were recorded using an ATR-IR spectrometer (Model 550, Magna Nicolet, Madison, WI, USA). HPLC studies were conducted on the Agilent 1200 Series HLPC system (Agilent Technologies, Santa Clara, CA, USA) equipped with a Zorbax Eclipse XDB- $\mathrm{C}_{18}$ column $(150 \mathrm{~mm} \times 4.6 \mathrm{~mm}, 5 \mu \mathrm{m}$ particle size $)$ and acetonitrile as the mobile phase at a flow rate of $0.4 \mathrm{~mL} / \mathrm{min}$. Each time a $10 \mu \mathrm{L}$ sample was injected and phenanthrene was detected at $254 \mathrm{~nm}$ wavelengths.

\section{Results and Discussion}

\subsection{Synthesis and Characterization of the Materials}

Poly- $\beta C D$ (1), Py $\beta C D$ (2), Poly-Py $\beta C D$ (3), Poly-SMP-Py $\beta C D$ (4) were prepared as shown in Scheme 1 and described in the experimental section. All materials were characterized by SEM, XPS, IR spectroscopy, and TGA.

\subsection{Scanning Electron Microscopy (SEM)}

SEM images of the $\beta C D$ (Figure 1a), Poly- $\beta C D$ (1, Figure 1b), Poly-Py $\beta C D$ (3, Figure 1c), and that of hybrid materials prepared by polymerization of Py $\beta C D$ in the presence of SMP $(4$, Figure 1e,f) show that morphological changes in the materials appeared at different stages. $\beta C D$ in the SEM images appears as a flake-like crystalline (Figure 1a) that has the typical morphology of $\beta C D$ powder [40]. In case of Poly- $\beta C D$, it appeared as a soft fibrous material due to the loss of crystallinity of $\beta C D$ by ECH-polymerization (Figure 1b) [41]. However, Poly-Py $\beta C D$ (3) showed an entirely different appearance and embossed "flora-like" structures were formed on the outer surface of the $\beta C D$ polymer (Figure 1c). This was probably due to the hydrophobic character induced by the pentynyl groups grafted on the $\beta C D$ surface. Comparison of the SMP (Figure 1d), and after its hybridization, (Figure 1e) clearly indicates that SMP were entrapped into the Py $\beta C D$ network during the polymerization process. This phenomenon is clearer at higher magnification (Figure 1f) where silica particles trapped in the soft, snowy structures of the poly-Py $\beta C D$ network could be easily seen. These results indicate successful coating of the SMP with Py $\beta C D$ polymer. 

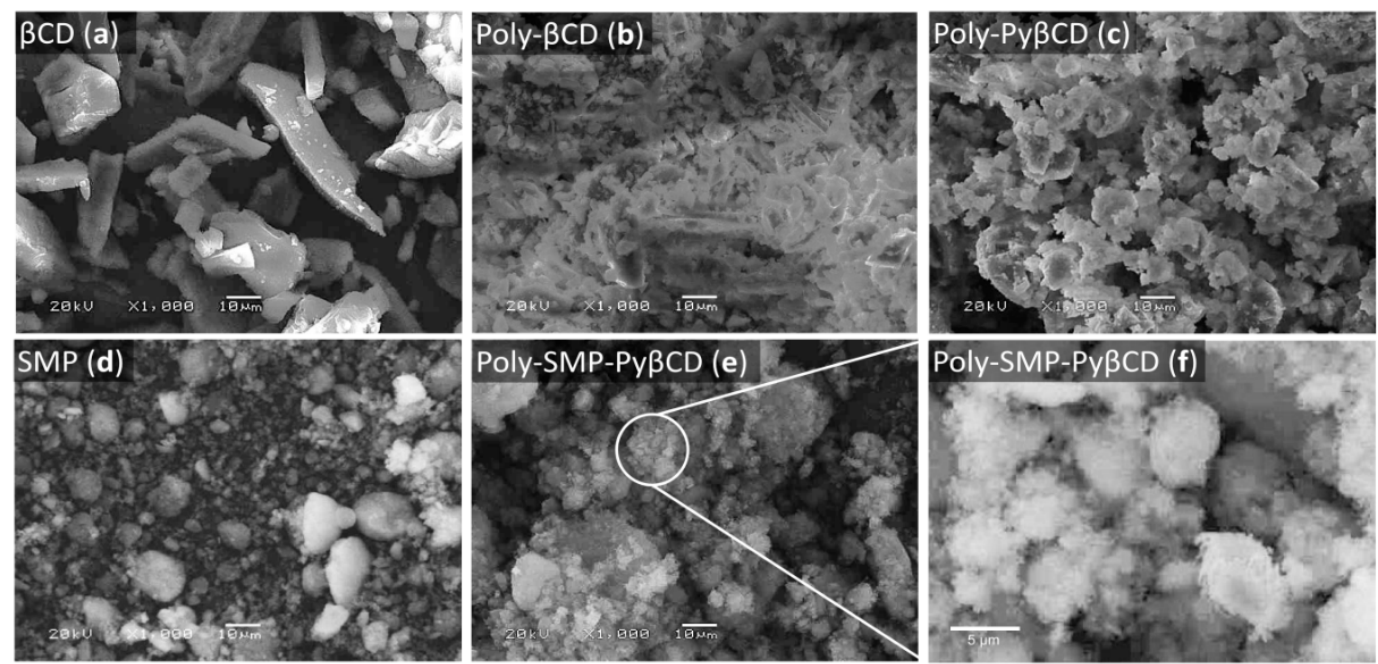

Figure 1. SEM images of the $\beta C D(\mathbf{a})$; Poly- $\beta C D(\mathbf{b})$; Poly-Py $\beta C D(3, \mathbf{c})$; silica micro-particles (SMP, d), and Poly-SMP-Py $\beta C D(4, \mathbf{e}, \mathbf{f})$.

\subsection{X-ray Photoelectron Spectroscopy (XPS)}

XPS is important analysis tool for detailed characterization of micro- and nanoparticles [42]. SMP and Poly-Py $\beta C D$ (4) were confirmed by XPS characterization to be successfully hybridized. The wide-scan XPS spectrum (Figure 2a) shows signals only for Si $(2 \mathrm{p}, 105 \mathrm{eV})$ and O (1s, $534 \mathrm{eV})$, while that of recorded after hybridization with Poly-SMP-PyßCD (4) shows signal for C (2p, $285 \mathrm{eV}$, Figure $2 b$ ) along with $\mathrm{Si}$ and $\mathrm{O}$. In elemental composition, a decrease in Si content from 29.59 to 19.09 at $\%$ after hybridization also give additional proof that the surface was successfully coated with the Poly-Py $\beta C D$ (compared to the elemental composition of Si in Figure 2a,b). The narrow-scan XPS spectrum (Figure 2c) of the $\mathrm{C} 1 \mathrm{~s}$ region displayed a signal at $285.0 \mathrm{eV}$ corresponding to $\mathrm{C}-\mathrm{C}$ bonds due to the presence of pentynyl groups and a signal at $286.23 \mathrm{eV}$ corresponding to $\mathrm{C}-\mathrm{O}$ bonds [43] from Poly-Py $\beta C D$. The ratio of $C-C / C-O$ is 0.26 and corresponds to 2.78 pentynyl groups per $\beta C D$ ring and is in agreement with the DS calculated from the NMR spectroscopy.
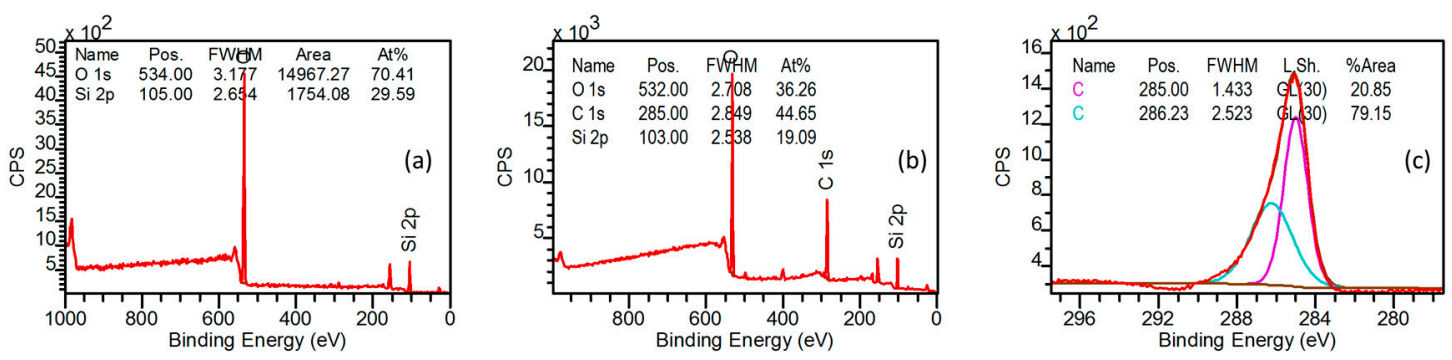

Figure 2. XPS wide scan spectra of unmodified SMP (a) and after hybridization with Poly-SMP-Py $\beta C D$ $(4, \mathbf{b})$ and narrow-scan of the C1s region after hybridization with Poly-SMP-PyßCD $(4, c)$.

\subsection{Applications for the Adsorption of Phenanthrene}

To study the phenanthrene adsorption from water, Poly-SMP-Py $\beta C D(4)$ was incubated with the phenanthrene solution with gentle agitation and samples were periodically and analyzed by HPLC. Results represented in Figure 3 show that phenanthrene concentration decreased continuously with the passage of time. For comparison, unmodified SMP was also used in parallel and results (Figure 3) show that, along with Poly-SMP-Py $\beta C D$ (4), unmodified SMP could also adsorb phenanthrene. However, the efficiency of phenanthrene-absorption was significantly improved in the case of the modified SMP (4). In the first hour, while SMP adsorbed 35\% of the phenanthrene from the 
solution, this ratio reached $46 \%$ for Poly-SMP-Py $\beta C D(4)$. As the time passes, the differences of the adsorbed amount of the phenanthrene between SMP and Poly-SMP-Py $\beta C D(4)$ increases, therefore, the concentration of phenanthrene dropped more rapidly for Poly-SMP-Py $\beta C D$ (4) compared to SMP. After $5 \mathrm{~h}$ of incubation, unmodified SMP and Poly-SMP-Py $\beta C D(4)$ removed, respectively, $78 \%$ and $89 \%$ of the phenanthrene. Afterwards, it remained almost unchanged (Figure 3) for the SMP, while Poly-SMP-Py $\beta C D$ (4) removed about $96 \%$ of the phenanthrene in $7 \mathrm{~h}$ (Figure 3). The higher phenanthrene removal efficiency of Poly-SMP-Py $\beta C D$ (4) probably originated from the inclusion complexation property of $\beta C D$ grafted on the SMP surface (4). Regarding the inclusion complexation mechanism, it is considered that it mainly occurs due to the hydrophobic interactions between phenanthrene and the $\beta C D$ cavity. In the presence of repulsive interactions between the hydrophobic phenanthrene and the surrounding aqueous environment, the more favorable interactions between the hydrophobic guest and apolar $\beta C D$ cavity are the main driving forces for the transfer of phenanthrene molecules from the water to the $\beta C D$ cavity $[13,44]$. For comparison, Poly- $\beta C D(\mathbf{1})$, without grafting on to the SMP, was also prepared and used for the removal of phenanthrene from the aqueous solution, but its partial solubility in water makes its recovery very difficult and makes the whole process very complex. On the other hand, $\operatorname{Py} \beta C D(2)$, itself, and its polymer (Poly-Py $\beta C D, 3)$, are insoluble in water and the hybrid material (4) of the Poly-Py $\beta C D(3)$ and SMP is a very efficient and easy to recover from the aqueous solution. Pentynylation of the $\beta C D$ not only changes its solubility behavior, but also introduces a strong non-polar character making it more applicable without altering its entrapment and removal capacity of phenanthrene molecules. For further confirmation that enhanced phenanthrene removal efficiency of the Poly-SMP-Py $\beta C D(4)$ was due to the encapsulation of phenanthrene into the $\beta C D$ cavity, the adsorbent was characterized by IR spectroscopy and TGA.

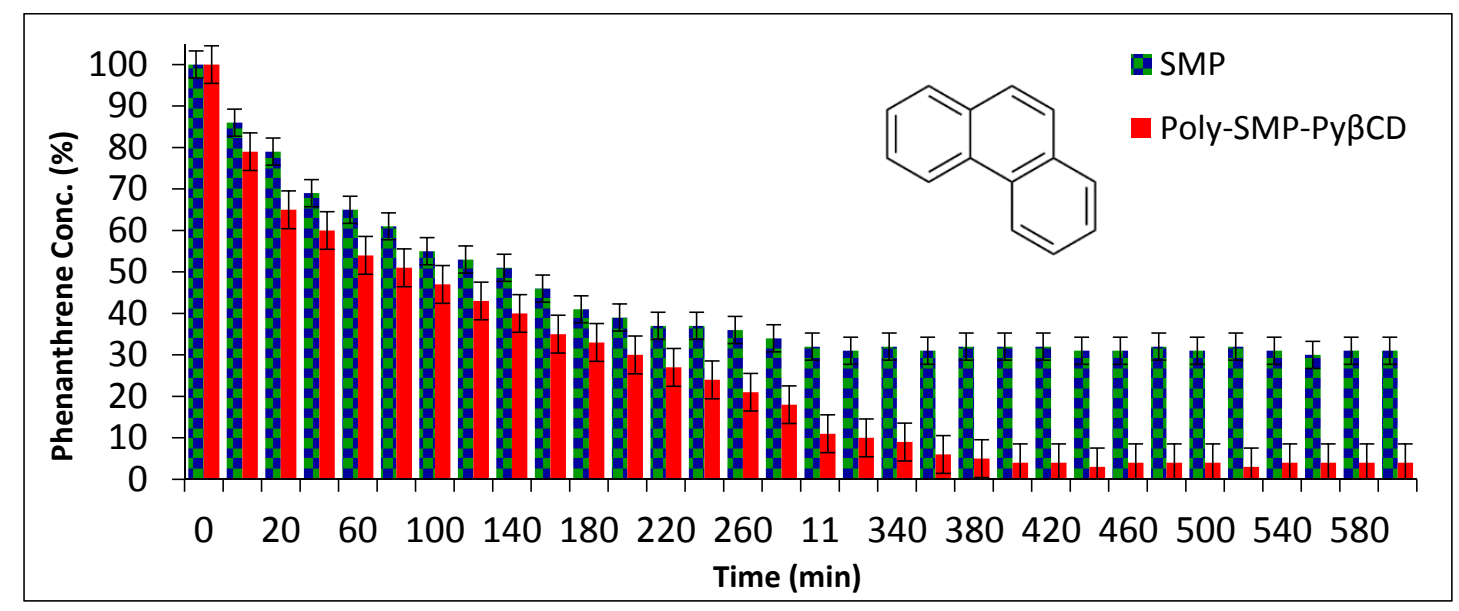

Figure 3. Phenanthrene (structure shown in the graph) adsorption from aqueous solution by the SMP and Poly-SMP-PyßCD (4).

\subsection{Infrared Spectroscopy}

Inclusion complex formation could also be confirmed by IR spectroscopy. The bands resulting from the encapsulated "guest" molecules are generally shifted or their intensities are altered [45]. The ATR-IR spectra of $\beta C D, P y \beta C D$ (2), Poly-Py $\beta C D$ (3), Poly-SMP-Py $\beta C D(4)$, and that of after encapsulation with phenanthrene are shown in Figure 4. Hydrogen-bonded -OH groups of the $\beta C D$ appeared at $3280 \mathrm{~cm}^{-1}$ while after its pentynylation (Py $\left.\beta C D, 2\right)$, a new signal due to the appearance of free-OH groups appeared at $3641 \mathrm{~cm}^{-1}$. This change indicates that pentynylation of $\beta C D$ introduced hydrophobic character and $\beta C D$ molecules were separated from each other leading to formation of "free $-\mathrm{OH}^{\prime}$ groups (Figure 4). Additionally, a very week signal in Py $\beta \mathrm{CD}$ due to $-\mathrm{C} \equiv \mathrm{C}-$ appeared at $2120 \mathrm{~cm}^{-1}$ but its intensity was very low. After polymerization, the signal at $3641 \mathrm{~cm}^{-1}$ (due to free $\mathrm{OH})$ was broaden due to the appearance of new kind of free-OH groups. The IR spectrum (Figure 4) 
of the Poly-SMP-Py $\beta C D(4)$, and that after creating inclusions with phenanthrene, look similar (except a few changes) and is considered a major characteristic of the $\beta C D$ host-guest inclusion complex as described by Li et al. [46]. Along with expected signals for Poly-SMP-Py $\beta C D$, the characteristic band for phenanthrene appeared between $2800-3200 \mathrm{~cm}^{-1}$ in the phenanthren-absorbed Poly-SMP-Py $\beta C D$ [47]. The signals of $\beta C D$ in Poly-SMP-Py $\beta C D(4)$ are characterized by intense bands at $3343 \mathrm{~cm}^{-1}$ due to $-\mathrm{OH}$ stretching vibrations in the primary $(\mathrm{C}-6-\mathrm{OH})$ or in the secondary $-\mathrm{OH}$ groups linked by the intramolecular $\mathrm{H}$-bonds ( $\mathrm{C}-2-\mathrm{OH}$ of one glucopyranose and $\mathrm{C}-3-\mathrm{OH}$ of the adjacent glucopyranose unit) $[12,45]$. After creating the inclusion complex with phenanthrene, this band was shifted to $3311 \mathrm{~cm}^{-1}$ due to the involvement of the $-\mathrm{OH}$ groups with phenanthrene molecules. In the region of $1400-1200 \mathrm{~cm}^{-1}$, the absorption bands at 1425, 1404, 1356, 1319, 1282, 1235, and $1192 \mathrm{~cm}^{-1}$ due to the deformation vibrations of the $\mathrm{C}-\mathrm{H}$ bonds in the primary and secondary $\mathrm{OH}$ groups in $\beta \mathrm{CD}$ were also shifted, respectively, to $1422,1401,1344,1317,1378,1228$, and $1178 \mathrm{~cm}^{-1}$. In the region of $1200-1030 \mathrm{~cm}^{-1}$, the absorption bands of the valence vibrations of the $\mathrm{C}-\mathrm{O}$ bonds in the ether and $-\mathrm{OH}$ groups of the $\beta C D$ were shifted from 1096 to 1055 and 1049 to $1031 \mathrm{~cm}^{-1}$. The region from 950 to $700 \mathrm{~cm}^{-1}$ in $\beta C D$ spectrum show the absorption bands at $931,845,750$, and $701 \mathrm{~cm}^{-1}$ belonging to the deformation vibrations of the $\mathrm{C}-\mathrm{H}$ bonds and the pulsation vibrations in glucopyranose cycle in $\beta C D$. In $\beta C D$-phenanthrene complex, these bands were shifted, respectively, to $926,843,734$, and $699 \mathrm{~cm}^{-1}$.

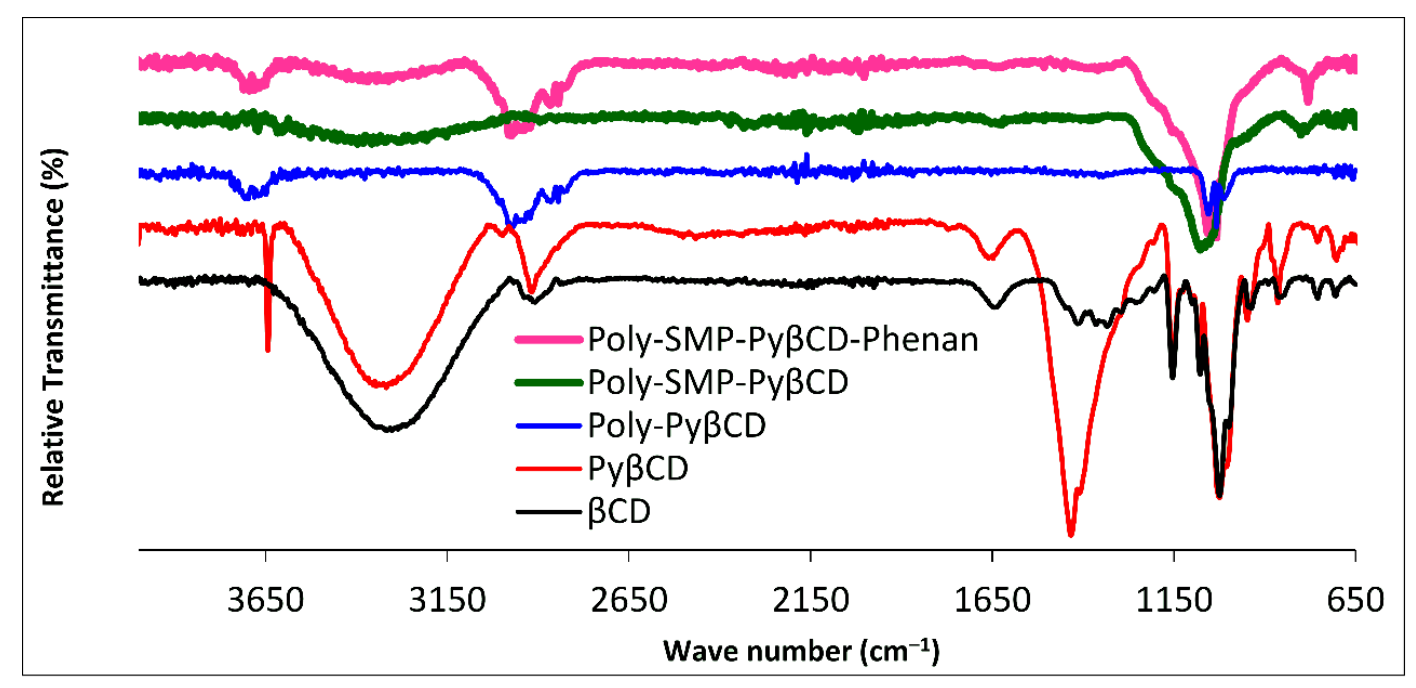

Figure 4. ATR-IR spectra of (respectively from bottom to top) $\beta C D, P y \beta C D$ (2); Poly-Py $\beta C D$ (3); Poly-SMP-Py $\beta C D(4)$; and that of after making inclusion complex with the phenanthrene.

Thus, all vibrations and bends of the $\beta C D$ were shifted to lower frequencies after complexation with phenanthrene. This observation is different from the reported data $[45,48]$ where all vibrations and bends of the $\beta C D$ were shifted to slightly higher frequencies due to the of the "guest" molecules into the $\beta C D$ cavity. This difference is due to the difference in the chemical structure of the "guest" molecules, i.e., guest molecules cause the in the vibrations and bend frequencies, but the nature of the shift (blue- or redshift) would depend upon the chemical nature of the guest molecules. These observations are in agreement with the reported literature [49].

\subsection{Thermal Gravimetric Analysis (TGA)}

TGA analyses of Poly-Py $\beta C D$ and the phenanthrene encapsulated in $\beta C D$ cavities provides information about the constituents and their quantities present in the composite material. It also allowed us to investigate their degradation kinetics and water loss [18-22]. Results indicate that the enhanced efficiency of the Poly-SMP-Py $\beta C D(4)$ compared to unmodified SMP was due to the inclusion complex formation between the $\beta C D$ cavity and phenanthrene. For this purpose, TGA was conducted 
on the samples to identify changes in the weight percent with respect to the increase in temperature. TGA was performed on Poly-Py $\beta C D$ (3), Poly-SMP-Py $\beta C D(4)$, phenanthrene, and after complexation of Poly-SMP-Py $\beta C D(4)$ with phenanthrene for the temperature range of 30 to $800^{\circ} \mathrm{C}$, and the results are plotted in Figure 5. Poly-Py $\beta C D$ (3) exhibits two separate weight losses areas; first, from $40-200{ }^{\circ} \mathrm{C}$ due to the loss of water molecules attached with $\mathrm{OH}$ by H-bonding in the $\beta \mathrm{CD}$ cavity, losing $1.96 \%$ weight, and second, from $200-345{ }^{\circ} \mathrm{C}$ due to the decomposition of the $\beta C D$ macrocycles and $23 \%$ of the original weight was lost in this region. Along with two major phases, there was also a third, and a bit slower, phase ranging from 345 to $512{ }^{\circ} \mathrm{C}$, losing $9 \%$ of the weight. Poly-SMP-Py $\beta C D$ (4) remained stable until $207^{\circ} \mathrm{C}$ and only $1.64 \%$ weight was lost due to moisture evaporation. This indicates that thermal stability of Poly-Py $\beta C D$ (3) was slightly improved after hybridization with SMP. Phenanthrene remained almost stable until $101{ }^{\circ} \mathrm{C}$ (the melting point of phenanthrene) and only $1.24 \%$ weight was lost due to moisture removal. After that, it degraded very rapidly and almost 100\% weight was lost from 101 to $183^{\circ} \mathrm{C}$. The Poly-SMP-Py $\beta C D /$ phenanthrene complex remained stable until $112{ }^{\circ} \mathrm{C}$, and only $1 \%$ weight, probably due to the evaporation of moisture present in the sample, was lost. This indicates that encapsulation of the phenanthrene in $\beta C D$ cavity has improved its thermal stability and is in agreement with the reported data $[36,37]$. Similar observations have been reported by Narayanan et al. [21] for encapsulating of poly( $\varepsilon$-caprolactone) in $\alpha$-cyclodextrin.

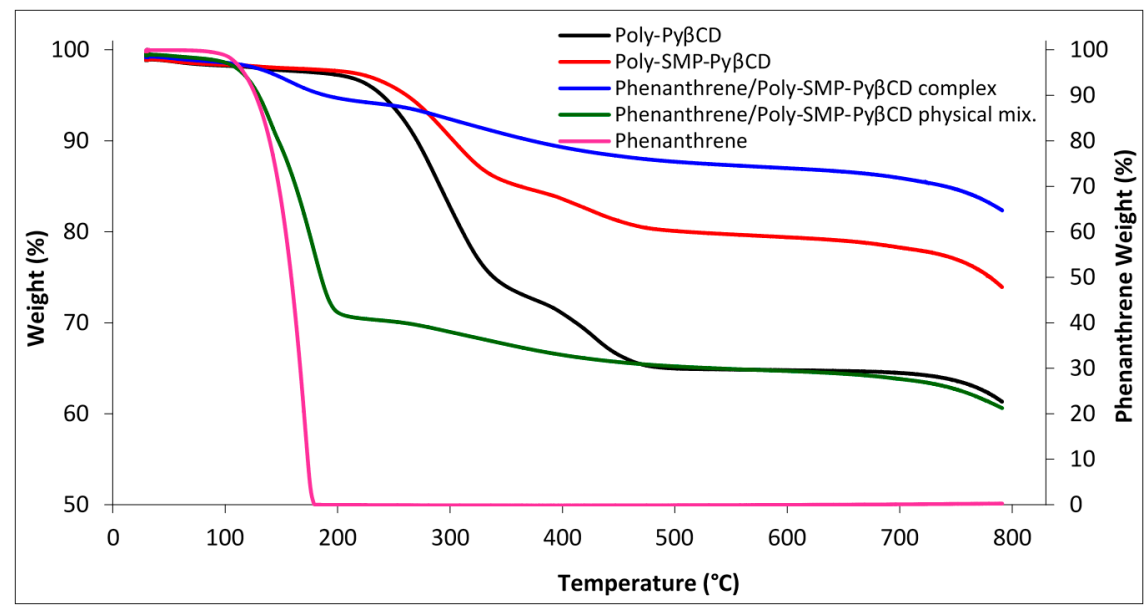

Figure 5. TGA analysis of the Poly-Py $\beta C D$, Poly-SMP-Py $\beta C D$, phenanthrere/Poly-SMP-Py $\beta C D$ complex, phenanthrene/Poly-SMP-Py $\beta C D$ physical mixture and pure phenanthrene. Weight loss of phenanthrene is shown on the right side of the graph while others on the left side of graph.

In comparison, thermal analysis was also done on the phenanthrene/Poly-SMP-Py $\beta C D$ physical mixture and pure phenanthrene to confirm that the improvement in phenanthrene stability was due to its inclusion complex with $\beta C D$. The physical mixture also remained stable until $101{ }^{\circ} \mathrm{C}$, followed by rapid degradation, and $27 \%$ of the weight was lost from 101 to $197^{\circ} \mathrm{C}$ followed by Poly-Py $\beta C D$ degradation $\left(197-340^{\circ} \mathrm{C}\right)$. The main degradation in pure $\beta C D$ was started at $200{ }^{\circ} \mathrm{C}$, in Poly-SMP-Py $\beta C D(4)$ at $207^{\circ} \mathrm{C}$, after making complexation with phenanthrene at $253^{\circ} \mathrm{C}$, while in the physical mixture, it started again at about $200^{\circ} \mathrm{C}$. In the same way, degradation of pure phenanthrene and in the physical mixture was started at $101^{\circ} \mathrm{C}$, while that of the inclusion complexation was started at $112{ }^{\circ} \mathrm{C}$. These results indicate that the formation of the inclusion complex has changed the thermal degradation properties of $\beta C D$ and phenanthrene, and that the improvement in the phenanthrene removal capacity of the Poly-SMP-Py $\beta C D(4)$ was due to the inclusion complexation of phenanthrene in the $\beta C D$ cavity. 


\section{Conclusions}

A hybrid material of silica micro-particles (SMP) and a polymer of pentynyl $\beta C D$ (Poly-Py $\beta C D$ ) was prepared and used for the phenanthrene removal from the aqueous solution. Results show that pentynyl groups induce a non-polar character to the $\beta C D$ polymer and make it insoluble in water. Phenanthrene capturing efficiency of the hybrid material (Poly-SMP-Py $\beta C D$ ) was improved significantly compared to the unmodified SMP. Infrared spectroscopy and thermal gravimetric analysis show that enhanced efficiency was due to the inclusion complexation formed between phenanthrene and $\beta C D$ cavity. It is probable that the hydrophobic nature of the pentynyl groups introduced on the $\beta C D$ surface also helps to attract phenanthrene towards the $\beta C D$ and plays a role in improving the adsorption capacity of the Poly-SMP-Py $\beta C D$. These results indicate that Poly-SMP-Py $\beta C D$ hybrid materials have a potential to be applied as molecular filters in water purification systems and also for waste water treatment.

Acknowledgments: This work was supported by WTU Joint Research Grants of Konkuk University. This research was also supported by Basic Science Research Program through the National Research Foundation of Korea (NRF) funded by the Ministry of Education (NRF-2015R1D1A1A01058686) SDG.

Author Contributions: Seunho Jung and Muhammad Nazir Tahir conceived and designed the experiments; Muhammad Nazir Tahir, Jae Min Choi and Daham Jeong and Eunae Cho analyzed the data and wrote the paper. Jae Min Choi and Muhammad Nazir Tahir performed the experiments. Jae-Hyuk Yu supervised and provide consulting during the project. All authors reviewed the manuscript.

Conflicts of Interest: The authors declare no conflict of interest.

\section{References}

1. Haritash, A.K.; Kaushik, C.P. Biodegradation aspects of polycyclic aromatic hydrocarbons (PAHs): A review. J. Hazard. Mater. 2009, 169, 1-15. [CrossRef] [PubMed]

2. Samanta, S.K.; Singh, O.V.; Jain, R.K. Polycyclic aromatic hydrocarbons: Environmental pollution and bioremediation. Trends Biotechnol. 2002, 20, 243-248. [CrossRef]

3. Viglianti, C.; Hanna, K.; De Brauer, C.; Germain, P. Removal of polycyclic aromatic hydrocarbons from aged-contaminated soil using cyclodextrins: Experimental study. Environ. Pollut. 2006, 140, 427-435. [CrossRef] [PubMed]

4. Kayaci, F.; Aytac, Z.; Uyar, T. Surface modification of electrospun polyester nanofibers with cyclodextrin polymer for the removal of phenanthrene from aqueous solution. J. Hazard. Mater. 2013, 261, $286-294$. [CrossRef] [PubMed]

5. Walcarius, A.; Mercier, L. Mesoporous organosilica adsorbents: Nanoengineered materials for removal of organic and inorganic pollutants. J. Mater. Chem. 2010, 20, 4478-4511. [CrossRef]

6. Yang, K.; Zhu, L.; Xing, B. Adsorption of polycyclic aromatic hydrocarbons by carbon nanomaterials. Environ. Sci. Technol. 2006, 40, 1855-1861. [CrossRef] [PubMed]

7. Ramesh, K.; Murthy, S.N.; Nageswar, Y.V.D. Novel and efficient aqueous phase synthesis of $N$-substituted azepines via tandem michael addition and cyclization in the presence of $\beta$-cyclodextrin. Tetrahedron Lett. 2011, 52, 2362-2366. [CrossRef]

8. Dora, C.P.; Trotta, F.; Kushwah, V.; Devasari, N.; Singh, C.; Suresh, S.; Jain, S. Potential of erlotinib cyclodextrin nanosponge complex to enhance solubility, dissolution rate, in vitro cytotoxicity and oral bioavailability. Carbohydr. Polym. 2016, 137, 339-349. [CrossRef] [PubMed]

9. Han, E.-M.; Kim, S.-H.; Ahn, J.; Kwak, H.-S. Optimizing cholesterol removal from cream using $\beta$-cyclodextrin cross-linked with adipic acid. Int. J. Dairy Technol. 2007, 60, 31-36. [CrossRef]

10. Hedges, A.R. Industrial applications of cyclodextrins. Chem. Rev. 1998, 98, 2035-2044. [CrossRef] [PubMed]

11. Reddy, M.A.; Bhanumathi, N.; Rao, K.R. Asymmetric synthesis of 2-azido-1-arylethanols from azido aryl ketone- $\beta$-cyclodextrin complexes and sodium borohydride in water. Chem. Commun. 2001, 1974-1975. [CrossRef]

12. Szejtli, J. Introduction and general overview of cyclodextrin chemistry. Chem. Rev. 1998, 98, 1743-1754. [CrossRef] [PubMed]

13. Del Valle, E.M.M. Cyclodextrins and their uses: A review. Process Biochem. 2004, 39, 1033-1046. [CrossRef] 
14. Rossi, B.; Venuti, V.; D’Amico, F.; Gessini, A.; Mele, A.; Punta, C.; Melone, L.; Crupi, V.; Majolino, D.; Masciovecchio, C. Guest-matrix interactions affect the solvation of cyclodextrin-based polymeric hydrogels: A UV Raman scattering study. Soft Matter 2016, 12, 8861-8868. [CrossRef] [PubMed]

15. Trotta, F.; Zanetti, M.; Cavalli, R. Cyclodextrin-based nanosponges as drug carriers. Beilstein J. Org. Chem. 2012, 8, 2091-2099. [CrossRef] [PubMed]

16. Trotta, F.; Cavalli, R. Characterization and applications of new hyper-cross-linked cyclodextrins. Compos. Interfaces 2009, 16, 39-48. [CrossRef]

17. Ferro, M.; Castiglione, F.; Punta, C.; Melone, L.; Panzeri, W.; Rossi, B.; Trotta, F.; Mele, A. Transport properties of ibuprofen encapsulated in cyclodextrin nanosponge hydrogels: A proton HR-MAS NMR spectroscopy study. J. Vis. Exp. 2016, 114. [CrossRef] [PubMed]

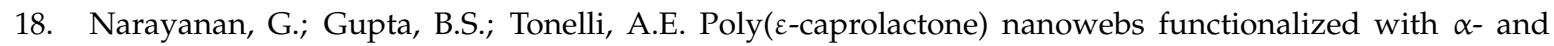
$\gamma$-cyclodextrins. Biomacromolcules 2014, 15, 4122-4133. [CrossRef] [PubMed]

19. Narayanan, G.; Ormond, B.R.; Gupta, B.S.; Tonelli, A.E. Efficient wound odor removal by $\beta$-cyclodextrin functionalized poly( $\varepsilon$-caprolactone) nanofibers. J. Appl. Polym. Sci. 2015, 132. [CrossRef]

20. Narayanan, G.; Gupta, B.S.; Tonelli, A.E. Enhanced mechanical properties of poly( $\varepsilon$-caprolactone) nanofibers produced by the addition of non-stoichiometric inclusion complexes of poly( $\varepsilon$-caprolactone) and $\alpha$-cyclodextrin. Polymer 2015, 76, 321-330. [CrossRef]

21. Narayanan, G.; Aguda, R.; Hartman, M.; Chung, C.-C.; Boy, R.; Gupta, B.S.; Tonelli, A.E. Fabrication and characterization of poly( $\varepsilon$-caprolactone) / $\alpha$-cyclodextrin pseudorotaxane nanofibers. Biomacromolcules 2016, 17, 271-279. [CrossRef] [PubMed]

22. Narayanan, G.; Chung, C.-C.; Aguda, R.; Boy, R.; Hartman, M.; Mehraban, N.; Gupta, B.S.; Tonelli, A.E. Correlation of the stoichiometries of poly( $\varepsilon$-caprolactone) and $\alpha$-cyclodextrin pseudorotaxanes with their solution rheology and the molecular orientation, crystallite size, and thermomechanical properties of their nanofibers. RSC Adv. 2016, 6, 111326-111336. [CrossRef]

23. Crini, G.; Morcellet, M. Synthesis and applications of adsorbents containing cyclodextrins. J. Sep. Sci. 2002, 25, 789-813. [CrossRef]

24. Landy, D.; Mallard, I.; Ponchel, A.; Monflier, E.; Fourmentin, S. Remediation technologies using cyclodextrins: An overview. Environ. Chem. Lett. 2012, 10, 225-237. [CrossRef]

25. Morin-Crini, N.; Crini, G. Environmental applications of water-insoluble $\beta$-cyclodextrin-epichlorohydrin polymers. Prog. Polym. Sci. 2013, 38, 344-368. [CrossRef]

26. Schofield, W.C.E.; Bain, C.D.; Badyal, J.P.S. Cyclodextrin-functionalized hierarchical porous architectures for high-throughput capture and release of organic pollutants from wastewater. Chem. Mater. 2012, 24, 1645-1653. [CrossRef]

27. Tahir, M.N.; Bork, C.; Risberg, A.; Horst, J.C.; Komoß, C.; Vollmer, A.; Mischnick, P. Alkynyl ethers of glucans: Substituent distribution in propargyl-, pentynyl- and hexynyldextrans and -amyloses and support for silver nanoparticle formation. Macromol. Chem. Phys. 2010, 211, 1648-1662. [CrossRef]

28. Rossi, B.; Venuti, V.; Paciaroni, A.; Mele, A.; Longeville, S.; Natali, F.; Crupi, V.; Majolino, D.; Trotta, F. Thermal fluctuations in chemically cross-linked polymers of cyclodextrins. Soft Matter 2015, 11, 2183-2192. [CrossRef] [PubMed]

29. Trotta, F.; Caldera, F.; Cavalli, R.; Mele, A.; Punta, C.; Melone, L.; Castiglione, F.; Rossi, B.; Ferro, M.; Crupi, V.; et al. Synthesis and characterization of a hyper-branched water-soluble $\beta$-cyclodextrin polymer. Beilstein J. Org. Chem. 2014, 10, 2586-2593. [CrossRef] [PubMed]

30. Celebioglu, A.; Demirci, S.; Uyar, T. Cyclodextrin-grafted electrospun cellulose acetate nanofibers via "click" reaction for removal of phenanthrene. Appl. Surf. Sci. 2014, 305, 581-588. [CrossRef]

31. Seglie, L.; Martina, K.; Devecchi, M.; Roggero, C.; Trotta, F.; Scariot, V. The effects of 1-MCP in cyclodextrin-based nanosponges to improve the vase life of dianthus caryophyllus cut flowers. Postharvest Biol. Technol. 2011, 59, 200-205. [CrossRef]

32. Martel, B.; Weltrowski, M.; Morcellet, J. Cyclodextrin Polymers and/or Cyclodextrin Derivatives with Complexing Properties and Ion-Exchange Properties and Method for the Production Thereof. U.S. Patent 6,660,804, 2 February 2002.

33. Trotta, F.; Tumiatti, W. Cross-Linked Polymers Based on Cyclodextrins for Removing Polluting Agents. U.S. Patent WO2003085002, 5 January 2005. 
34. Crini, G. Recent developments in polysaccharide-based materials used as adsorbents in wastewater treatment. Prog. Polymer Sci. 2005, 30, 38-70. [CrossRef]

35. Concheiro, A.; Alvarez-Lorenzo, C. Chemically cross-linked and grafted cyclodextrin hydrogels: From nanostructures to drug-eluting medical devices. Adv. Drug Deliv. Rev. 2013, 65, 1188-1203. [CrossRef] [PubMed]

36. Gidwani, B.; Vyas, A. Synthesis, characterization and application of epichlorohydrin- $\beta$-cyclodextrin polymer. Colloids Surf. B Biointerfaces 2014, 114, 130-137. [CrossRef] [PubMed]

37. Li, J.; Xiao, H.; Li, J.; Zhong, Y. Drug carrier systems based on water-soluble cationic $\beta$-cyclodextrin polymers. Int. J. Pharm. 2004, 278, 329-342. [CrossRef] [PubMed]

38. Huesemann, M.H.; Fortman, T.J.; Riley, R.G.; Thompson, C.J.; Wang, Z.; Truex, M.J.; Peyton, B. Slow desorption of phenanthrene from silica particles: Influence of pore size, pore water, and aging time. In Contaminated Soils, Sediments and Water: Successes and Challenges; Calabrese, E.J., Kostecki, P.T., Dragun, J., Eds.; Springer: Boston, MA, USA, 2006.

39. Tahir, M.N.; Adnan, A.; Mischnick, P. Lipase immobilization on o-propargyl and o-pentynyl dextrans and its application for the synthesis of click beetle pheromones. Process Biochem. 2009, 44, 1276-1283. [CrossRef]

40. Yallapu, M.M.; Jaggi, M.; Chauhan, S.C. Beta-cyclodextrin-curcumin self-assembly enhances curcumin delivery in prostate cancer cells. Colloids Surf. B Biointerfaces 2010, 79, 113-125. [CrossRef] [PubMed]

41. Pratt, D.Y.; Wilson, L.D.; Kozinski, J.A.; Mohart, A.M. Preparation and sorption studies of $\beta$-cyclodextrin/ epichlorohydrin copolymers. J. Appl. Polym. Sci. 2010, 116, 2982-2989. [CrossRef]

42. Baer, D.R.; Gaspar, D.J.; Nachimuthu, P.; Techane, S.D.; Castner, D.G. Application of surface chemical analysis tools for characterization of nanoparticles. Anal. Bioanal. Chem. 2010, 396, 983-1002. [CrossRef] [PubMed]

43. El-Nahhal, I.M.; El-Shetary, B.A.; Mustafa, A.E.-K.B.; El-Ashgar, N.M.; Livage, J.; Chehimi, M.M.; Roberts, A. Structural characterization of immobilized-polysiloxane iminobis( $n$-diethylenediamineacetamide) ligand system. Solid State Sci. 2003, 5, 1395-1406. [CrossRef]

44. Badr, T.; Hanna, K.; de Brauer, C. Enhanced solubilization and removal of naphthalene and phenanthrene by cyclodextrins from two contaminated soils. J. Hazard. Mater. 2004, 112, 215-223. [CrossRef] [PubMed]

45. Roik, N.V.; Belyakova, L.A. Thermodynamic, ir spectral and X-ray diffraction studies of the " $\beta$-cyclodextrinpara-aminobenzoic acid" inclusion complex. J. Incl. Phenom. Macrocycl. Chem. 2010, 69, 315-319. [CrossRef]

46. Li, N.; Liu, J.; Zhao, X.; Gao, Y.A.; Zheng, L.; Zhang, J.; Yu, L. Complex formation of ionic liquid surfactant and $\beta$-cyclodextrin. Colloids Surf. A Physicochem. Eng. Asp. 2007, 292, 196-201. [CrossRef]

47. Wu, M.L.; Nie, M.Q.; Wang, X.C.; Su, J.M.; Cao, W. Analysis of phenanthrene biodegradation by using FTIR, UV and GC-MS. Spectrochim. Acta Part A Mol. Biomol. Spectrosc. 2010, 75, 1047-1050. [CrossRef] [PubMed]

48. Periasamy, R.; Kothainayaki, S.; Sivakumar, K. Preparation, physicochemical analysis and molecular modeling investigation of 2,2'-bipyridine: $\beta$-cyclodextrin inclusion complex in solution and solid state. J. Mol. Struct. 2015, 1100, 59-69. [CrossRef]

49. El-Nahhal, Y.Z.; Safi, J.M. Adsorption of phenanthrene on organoclays from distilled and saline water. J. Colloid Interface Sci. 2004, 269, 265-273. [CrossRef]

(c) 2017 by the authors; licensee MDPI, Basel, Switzerland. This article is an open access article distributed under the terms and conditions of the Creative Commons Attribution (CC-BY) license (http://creativecommons.org/licenses/by/4.0/). 